\title{
Mineralogical response of the Mediterranean crustose coralline alga Lithophyllum cabiochae to near-future ocean acidification and warming
}

\author{
Merinda C. Nash $^{1,2}$, Sophie Martin ${ }^{3}$, and Jean-Pierre Gattuso ${ }^{4,5}$ \\ ${ }^{1}$ Research School of Physics and Engineering, The Australian National University, Canberra, Australia \\ ${ }^{2}$ Department of Botany, Smithsonian Institution, Washington, DC, USA \\ ${ }^{3}$ Sorbonne Universités, UPMC Université Paris 06, UMR7144, Station Biologique de Roscoff, 29680 Roscoff, France \\ ${ }^{4}$ CNRS, UMR7144, Laboratoire Adaptation et Diversité en Milieu Marin, Station Biologique de Roscoff, \\ 29680 Roscoff, France \\ ${ }^{5}$ Institute for Sustainable Development and International Relations, Sciences Po, 27 rue Saint Guillaume, \\ 75007 Paris, France
}

Correspondence to: Merinda C. Nash (merinda.nash@anu.edu.au)

Received: 26 April 2016 - Published in Biogeosciences Discuss.: 2 May 2016

Revised: 28 September 2016 - Accepted: 30 September 2016 - Published: 1 November 2016

\begin{abstract}
Red calcareous coralline algae are thought to be among the organisms most vulnerable to ocean acidification due to the high solubility of their magnesium calcite skeleton. Although skeletal mineralogy is proposed to change as $\mathrm{CO}_{2}$ and temperature continue to rise, there is currently very little information available on the response of coralline algal carbonate mineralogy to near-future changes in $p \mathrm{CO}_{2}$ and temperature. Here we present results from a 1 -year controlled laboratory experiment to test mineralogical responses to $p \mathrm{CO}_{2}$ and temperature in the Mediterranean crustose coralline alga (CCA) Lithophyllum cabiochae. Our results show that $\mathrm{Mg}$ incorporation is mainly constrained by temperature $\left(+1 \mathrm{~mol} \% \mathrm{MgCO}_{3}\right.$ for an increase of $\left.3^{\circ} \mathrm{C}\right)$, and there was no response to $p \mathrm{CO}_{2}$. This suggests that $L$. cabiochae thalli have the ability to buffer their calcifying medium against ocean acidification, thereby enabling them to continue to deposit magnesium calcite with a significant mol $\% \mathrm{MgCO}_{3}$ under elevated $p \mathrm{CO}_{2}$. Analyses of CCA dissolution chips showed a decrease in $\mathrm{Mg}$ content after 1 year for all treatments, but this was affected neither by $p \mathrm{CO}_{2}$ nor by temperature. Our findings suggest that biological processes exert a strong control on calcification on magnesium calcite and that CCA may be more resilient under rising $\mathrm{CO}_{2}$ than previously thought. However, previously demonstrated increased skeletal dissolution with ocean acidification will
\end{abstract}

still have major consequences for the stability and maintenance of Mediterranean coralligenous habitats.

\section{Introduction}

Coralline algae are thought to be among the organisms most vulnerable to ocean acidification (decreasing $\mathrm{pH}$ and increasing $p \mathrm{CO}_{2}$ ). This is because their skeletons consist of magnesium calcite and the solubility of magnesium calcite $\left(>8_{-}\right.$ $\left.12 \mathrm{~mol}_{\%} \mathrm{MgCO}_{3}\right)$ is greater than the solubility of the other forms of calcium carbonate $\left(\mathrm{CaCO}_{3}\right)$, calcite (low magnesium calcite, $<8 \mathrm{~mol} \%$ ) and aragonite (Andersson et al., 2008). Consequently, it has been suggested that coralline algae, both articulated and crustose coralline algae (CCAs), will be among the first organisms to dissolve in the context of ocean acidification (Andersson et al., 2008). However, the presence of magnesium calcite phases with lower solubility, such as dolomite $\left(50 \mathrm{~mol} \% \mathrm{MgCO}_{3}\right.$; Nash et al., 2011) within the cells of tropical CCA, results in reduced dissolution rates (Kline et al., 2012; Nash et al., 2013a). Potential resilience of coralline algae to ocean acidification may thus occur through changes in skeletal mineralogy either by producing calcite with lower Mg content (Chave, 1954; Agegian, 1985; Stanley et al., 2002; Ries, 2011; Egilsdottir et al., 
2013) or by favouring accumulation of $\mathrm{CaCO}_{3}$ forms with lower solubility such as dolomite (Diaz-Pulido et al., 2014). The Mg content in coralline algae is also known to vary as a function of seawater temperature (Agegian, 1985; Halfar et al., 2000; Kamenos et al., 2008; Hetzinger et al., 2009; Caragnano et al., 2014; Diaz-Pulido et al., 2014), which is considered to exert a primary control by facilitating $\mathrm{Mg}$ incorporation into the skeleton (Kamenos et al., 2008). However, there is currently limited information available on the response of the mineralogy of coralline algae to near-future changes of $p \mathrm{CO}_{2}$ and temperature, and none on temperate CCA.

The response of dead CCA crust to varying $\mathrm{pH}$ conditions is also of interest as it is the preservation of this crust that underpins many of the coralligenous habitats. It has been proposed that as $\mathrm{CO}_{2}$ rises, calcite with higher $\mathrm{Mg}$ contents will dissolve and may re-precipitate as lower Mg phases (Andersson et al., 2008). This would result in lower average mol \% $\mathrm{MgCO}_{3}$ of magnesium calcite. As it is proposed that calcite with lower $\mathrm{Mg}$ contents is more thermodynamically stable than that with higher Mg content, this could provide a positive feedback mechanism to stabilize the calcium carbonate skeletons. As of yet, there has been no experimental work on the magnesium calcite skeletons of CCA to test this proposal. An experiment performed on skeletal chips of Lithophyllum cabiochae reported rates of dissolution 2 to 4 times higher under elevated $p \mathrm{CO}_{2}$ than under ambient $p \mathrm{CO}_{2}$ (Martin and Gattuso, 2009). These dissolution chip samples offer an opportunity to test the theory that higher $\mathrm{Mg}$ phases of magnesium calcite would dissolve differentially from the CCA crusts, potentially increasing the stability of the dead substrate.

We investigated experimentally the response of the carbonate mineralogy of the CCA Lithophyllum cabiochae, one of the main calcareous components of coralligenous habitats in the Mediterranean Sea, after 12 months of exposure to ocean acidification and warming. The hypotheses tested are as follows:

- The Mg content of the new growth would increase with temperature.

- The Mg content of the new growth would decrease under elevated $p \mathrm{CO}_{2}$.

- The Mg content of dead dissolution chips would decrease with elevated $p \mathrm{CO}_{2}$.

\section{Materials and methods}

Full experimental details, carbonate chemistry, growth, respiration, photosynthesis, net calcification and dissolution rates can be found in Martin and Gattuso (2009) and Martin et al. (2013a). A summary follows. Specimens of the
CCA Lithophyllum cabiochae (Boudouresque \& Verlaque) Athanasiadis were collected in the coralligenous community at ca. $25 \mathrm{~m}$ depth in the Bay of Villefranche (NW Mediterranean Sea, France; $43^{\circ} 40.73^{\prime} \mathrm{N}, 07^{\circ} 19.39^{\prime} \mathrm{E}$ ) on $10 \mathrm{July}$ 2006 and transported to the laboratory in thermostated tanks within $1 \mathrm{~h}$. Flat thalli were selected for the experiments and were thoroughly cleaned of epiphytic organisms. They were randomly assigned in four $26 \mathrm{~L}$ aquaria and reared for 1 year (July 2006-August 2007) in four treatments:

1. ambient $p \mathrm{CO}_{2}$ (ca. $\left.400 \mu \mathrm{atm}\right)$ and ambient temperature ( $T$, i.e. the temperature at $25 \mathrm{~m}$ depth in the Bay of Villefranche; control, labelled 400T),

2. ambient $p \mathrm{CO}_{2}$ and elevated temperature $\left(T+3{ }^{\circ} \mathrm{C} ; 400\right.$ $T+3)$

3. elevated $p \mathrm{CO}_{2}$ (ca. $\left.700 \mu \mathrm{atm}\right)$ and ambient temperature (700 T),

4. elevated $p \mathrm{CO}_{2}$ and elevated temperature (700 T+3).

A further set of CCA thalli were air-dried until dead and placed in the tanks in December 2006 for the remaining 8 months of the experimental period to measure rates of dissolution (Martin and Gattuso, 2009). The aquaria were continuously supplied with Mediterranean seawater from two $110 \mathrm{~L}$ header tanks in which $p \mathrm{CO}_{2}$ was adjusted by bubbling ambient air (ambient $p \mathrm{CO}_{2}$ ) or $\mathrm{CO}_{2}$-enriched air (elevated $p \mathrm{CO}_{2}$ ) obtained by mixing pure $\mathrm{CO}_{2}$ to ambient air. Temperature was gradually changed according to the season from $T=13.3$ to $22.0^{\circ} \mathrm{C}\left(T+3=16.3\right.$ to $\left.25.0^{\circ} \mathrm{C}\right)$. Irradiance was set to the mean in situ daily irradiance at $25 \mathrm{~m}$ depth in the Bay of Villefranche and was adjusted seasonally from 6 to $35 \mu$ mol photons $\mathrm{m}^{-2} \mathrm{~s}^{-1}$. The photoperiod was adjusted weekly according to natural fluctuations and varied from 9:15 (light: dark ratio - winter) to $15: 9$ (summer). The annual means of the carbonate chemistry parameters are shown in Table 1. At the end of the experiment all crusts were air-dried. Four sets of crust were sampled for X-ray diffraction (XRD): (1) the new crusts grown from the bottom face of the main thalli (Fig. 1), (2) the pink surficial crust on the original thalli, (3) the original thalli (Fig. 1), and (4) pieces of dead crust that had been used for dissolution tests. New crusts were confirmed to have grown during the experiment as the preexisting crust was cleaned and photographed at the time of collection and these growths were not present at that time. For the new crusts, sets of four to five crust fragments similar in size (ca. $2-3 \mathrm{~mm}$ in diameter) and thickness $(\sim 1 \mathrm{~mm}$ thick) were randomly selected from eight thalli per treatment. To obtain sufficient material for XRD analyses of the new thalli, three to four crust fragments were used from each alga. For the original thalli and dissolution chips, subsamples $\sim 2-3 \mathrm{~mm}$ thick were cut off the sides. The pink surface of the original thalli was sampled by gently scraping with a razor ensuring not to scrape into 
Table 1. Parameters of the carbonate system in each treatment. The values reported are means ( \pm standard error) of 191 to 194 data collected from July 2006 to August 2007. The $\mathrm{pH}\left(\mathrm{pH}_{\mathrm{T}}\right.$, on the total scale) and total alkalinity $\left(A_{\mathrm{T}}\right)$ were measured while other parameters were calculated. $p \mathrm{CO}_{2}, \mathrm{CO}_{2}$ partial pressure; $C_{\mathrm{T}}$, dissolved inorganic carbon; $\Omega_{\mathrm{c}}$ and $\Omega_{\mathrm{a}}$, saturation state of seawater with respect to calcite and aragonite.

\begin{tabular}{lccccccccc}
\hline Treatment & $\begin{array}{c}\mathrm{pH}_{\mathrm{T}} \\
(\text { total scale) }\end{array}$ & $\begin{array}{c}A_{\mathrm{T}} \\
\left(\mathrm{mmol} \mathrm{kg}^{-1}\right)\end{array}$ & $\begin{array}{c}\mathrm{CO}_{2} \\
(\mu \mathrm{atm})\end{array}$ & $\begin{array}{c}\mathrm{CO}_{2} \\
\left(\mathrm{mmol} \mathrm{kg}^{-1}\right)\end{array}$ & $\begin{array}{c}\mathrm{CO}_{3}^{2-} \\
\left(\mathrm{mmol} \mathrm{kg}^{-1}\right)\end{array}$ & $\begin{array}{c}\mathrm{HCO}_{3}^{-} \\
\left(\mathrm{mmol} \mathrm{kg}^{-1}\right)\end{array}$ & $\begin{array}{c}C_{\mathrm{T}} \\
\left(\mathrm{mmol} \mathrm{kg}^{-1}\right)\end{array}$ & $\Omega_{\mathrm{c}}$ & $\Omega_{\mathrm{a}}$ \\
\hline $400 T$ & $8.08 \pm 0.00$ & $2.516 \pm 0.004$ & $397 \pm 2$ & $0.014 \pm 0.000$ & $0.226 \pm 0.001$ & $1.974 \pm 0.003$ & $2.213 \pm 0.002$ & $5.26 \pm 0.03$ & $3.41 \pm 0.02$ \\
$400 T+3$ & $8.05 \pm 0.00$ & $2.519 \pm 0.004$ & $436 \pm 3$ & $0.014 \pm 0.000$ & $0.233 \pm 0.001$ & $1.962 \pm 0.004$ & $2.208 \pm 0.002$ & $5.43 \pm 0.03$ & $3.55 \pm 0.02$ \\
$700 T$ & $7.87 \pm 0.00$ & $2.517 \pm 0.004$ & $703 \pm 3$ & $0.024 \pm 0.000$ & $0.152 \pm 0.001$ & $2.155 \pm 0.003$ & $2.331 \pm 0.002$ & $3.54 \pm 0.03$ & $2.30 \pm 0.02$ \\
$700 T+3$ & $7.85 \pm 0.00$ & $2.523 \pm 0.004$ & $753 \pm 3$ & $0.024 \pm 0.000$ & $0.159 \pm 0.001$ & $2.144 \pm 0.004$ & $2.326 \pm 0.003$ & $3.72 \pm 0.03$ & $2.43 \pm 0.02$ \\
\hline
\end{tabular}

(a)

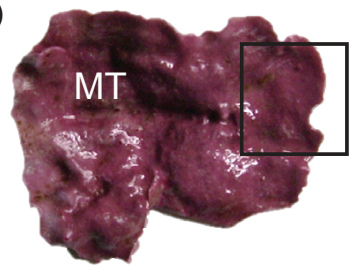

Top face

(b)

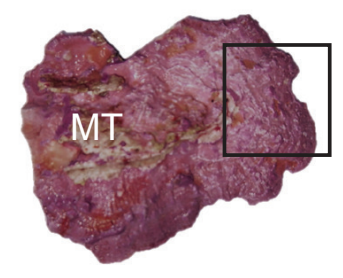

Bottom face
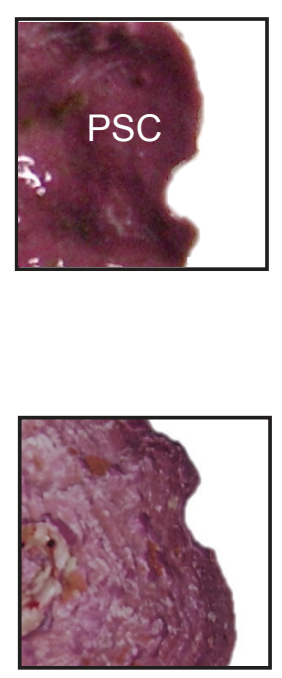

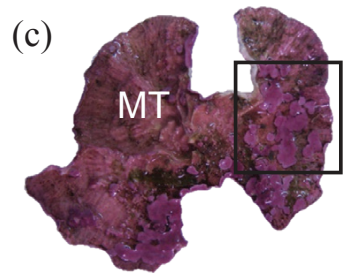

Bottom face
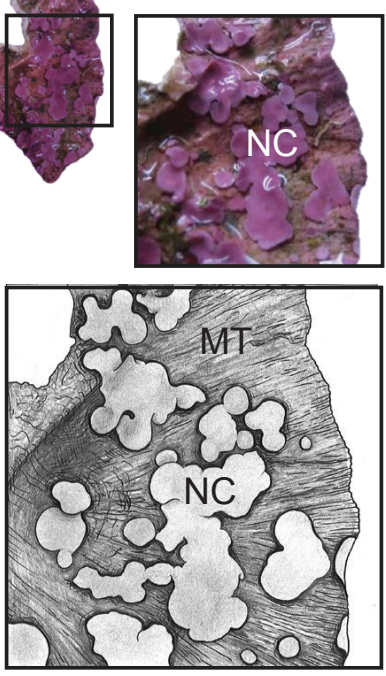

Figure 1. (a) Top face of the main thallus (MT) of L. cabiochae showing the pink surficial crust (PSC) and bottom faces (b) free of crusts at the time of collection and (c) with new crusts grown during the experimental period (photos and drawing by S. Martin).

the white crust underneath. This uppermost surface was presumed to have grown during the experiment and sampled instead of the surfaces of the new crusts as there was not a large enough surface area on the new protrusions to collect sufficient pink crust for analyses. Scrapings from five algae from each treatment were required in order to obtain enough material for one XRD test. The depth of the pink-pigmented crust was $\sim 200-500 \mu \mathrm{m}$, but only the surface is sampled by scraping on the top with the aim of collecting predominantly epithallial material. However, we do not refer to it as epithallus because by this sampling method we cannot confirm that no sub-perithallial crust has been included; hence, surficial pink crust is the most accurate description of this subsample. Our development of this method has shown that if too much pressure is applied during the scraping then substantial amounts of perithallial crust, which also can be pink-pigmented, may be unintentionally sampled.

The $\mathrm{mol} \% \mathrm{MgCO}_{3}$ of the crust fragments was determined via XRD using a Siemens D501 Bragg-Brentano diffractometer equipped with a graphite monochromator and scin- tillation detector, using $\mathrm{CuK} \alpha$ radiation. Crust fragments were crushed and powdered with fluorite $\left(\mathrm{CaF}_{2}\right)$ added as an internal standard. The coralline crust and fluorite are ground together with a mortar and pestle. Enough fluorite was added to obtain a clear peak; this is usually between 5 and $20 \mathrm{wt} \%$ but not specifically weighed. Powdered samples were mounted on a low background quartz slide. For the pink surficial crust, more fluorite $(30-50 \%)$ was added to obtain enough powder to cover the centre of the quartz slide. $\mathrm{Mg}$ content of calcite was calculated from the (104) peak position, and any asymmetry present was quantified as described in Nash et al. (2013b). XRD scans with 25$32^{\circ} 2 \theta$ scan length were processed using EVA Diffrac Plus software packages and interpreted following procedures described Nash et al. (2013b) and further developed in DiazPulido et al. (2014). XRD measurements had a reproducibility of $\pm 0.11 \mathrm{~mol} \%$ (standard deviation; $n=3$ analytical repeats of sample $700 T+3$ ).

The effects of $p \mathrm{CO}_{2}$ and temperature were assessed by two-way ANOVAs and followed by Tukey HSD post hoc 
Table 2. ANOVA testing the effect of $p \mathrm{CO}_{2}$ and temperature on skeletal mol \% $\mathrm{MgCO}_{3}$ in (a) new crusts, (b) main thalli, and (c) dissolution chips of Lithophyllum cabiochae.

\begin{tabular}{lrrrr}
\hline Source & $\mathrm{d} f$ & $\mathrm{MS}$ & $F$ & $p$ \\
\hline (a) New crusts & & & & \\
\hline$p \mathrm{CO}_{2}$ & 1 & 0.000005 & 0.223 & 0.65 \\
Temperature $_{p \mathrm{C}_{2} \times \text { temperature }}$ & 1 & 0.000701 & 28.620 & $<0.0001$ \\
Error & 28 & 0.000011 & 0.444 & 0.51 \\
& & & & \\
\hline
\end{tabular}

(b) Main thalli

\begin{tabular}{lrrrr}
\hline$p \mathrm{CO}_{2}$ & 1 & 0.000014 & 0.601 & 0.44 \\
Temperature & 1 & 0.000048 & 2.094 & 0.16 \\
$p \mathrm{CO}_{2} \times$ temperature & 1 & 0.000042 & 1.844 & 0.19 \\
Error & 28 & 0.000023 & &
\end{tabular}

(c) Dissolution chips

\begin{tabular}{lrrrr}
\hline$p \mathrm{CO}_{2}$ & 1 & 0.000003 & 0.143 & 0.71 \\
Temperature & 1 & 0.000005 & 0.218 & 0.64 \\
$p \mathrm{CO}_{2} \times$ temperature & 1 & 0.000014 & 0.663 & 0.42 \\
Error & 28 & 0.000021 & & \\
\hline
\end{tabular}

tests. Normality of the data and homoscedasticity were checked by the Kolmogorov-Smirnov test and Levene's test, respectively. A $t$ test was completed to compare asymmetry differences between the main thalli and dissolution chips.

\section{Results}

In general, the $\mathrm{Mg}$ content of the CCAs increased with temperature but was not affected by $\mathrm{CO}_{2}$ (Fig. 2). Dissolution chips had lower $\mathrm{Mg}$ content than the main thalli and neither the main thalli (pre-experimental crust) nor the dissolution chips showed any trends with temperature or $\mathrm{CO}_{2}$ (Table 2).

\subsection{New crust}

XRD results indicate that the new crusts of $L$. cabiochae are entirely calcitic (magnesium calcite). The mean $( \pm$ standard deviation) $\mathrm{Mg}$ contents were 15.2 $\pm 0.7,16.0 \pm 0.5$, $15.0 \pm 0.5$, and $16.1 \pm 0.3 \mathrm{~mol} \% \mathrm{MgCO}_{3}$ in the $400 T$, $400 T+3,700 T$, and $700 T+3$ treatments, respectively (Fig. 2, the complete dataset is provided in Supplement Table S1). The magnesium calcite peaks were symmetrical indicating there was neither dolomite nor magnesite present. The $\mathrm{Mg}$ content was significantly affected by temperature (two-way ANOVA, $p<0.0001$ ), being about $1 \mathrm{~mol} \%$ $\mathrm{MgCO}_{3}$ higher at elevated temperature $\left(+3{ }^{\circ} \mathrm{C}\right)$ relative to ambient temperature at both $p \mathrm{CO}_{2}$ levels, it but was not affected by $p \mathrm{CO}_{2}$ (Fig. 2; Table 2a).

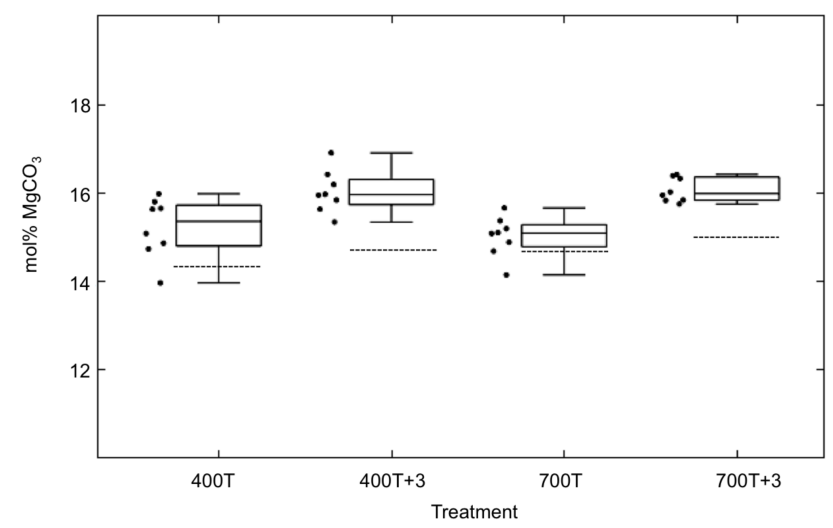

Figure 2. XRD results for new crust and pink surficial growth from the 400 and $700 \mu \mathrm{atm}$ treatments, in ambient temperature and ambient $+3{ }^{\circ} \mathrm{C}$. Dashed lines show the mean mol $\% \mathrm{MgCO}_{3}$ for pink surficial growth. The box plots represent the new crust and the dots are individual data points. The boxes represent the 25 th and 75 th percentiles. The horizontal bold line is the median value, and the whiskers are minimum and maximum values.

Table 3. ANOVA testing the effect of $p \mathrm{CO}_{2}$ and temperature on difference in asymmetry mol $\% \mathrm{MgCO}_{3}$ in (a) main thalli and (b) dissolution chips of Lithophyllum cabiochae.

\begin{tabular}{lrrrr}
\hline Source & $\mathrm{d} f$ & $\mathrm{MS}$ & $F$ & $p$ \\
\hline (a) Main thalli & & & & \\
\hline$p \mathrm{CO}_{2}$ & 1 & 0.000008 & 0.569 & 0.46 \\
Temperature & 1 & 0.000006 & 0.441 & 0.51 \\
$p \mathrm{CO}_{2} \times$ temperature & 1 & 0.000007 & 0.489 & 0.49 \\
Error & 28 & 0.000013 & & \\
\hline (b) Dissolution chips & & & & \\
\hline$p \mathrm{CO}_{2}$ & 1 & 0.000022 & 3.871 & 0.06 \\
Temperature & 1 & 0.000001 & 0.190 & 0.67 \\
$p \mathrm{CO}_{2} \times$ temperature & 1 & 0.000005 & 0.944 & 0.34 \\
Error & 28 & 0.000006 & & \\
\hline
\end{tabular}

\subsection{Pink surficial crusts}

The pink surficial crusts were also entirely magnesium calcite. The $\mathrm{Mg}$ content was 14.3, 14.6, 14.6, and $15 \mathrm{~mol} \%$ $\mathrm{MgCO}_{3}$ in the $400 T, 400 T+3,700 T$, and $700 T+3$ treatments, respectively (Fig. 2). There is no standard deviation or statistical analysis of the pink surficial crust results because only one analysis was performed on material from five thalli combined for each treatment.

\subsection{Main thalli}

The mean $( \pm \mathrm{SD}) \mathrm{Mg}$ contents in the main thalli were $16.0 \pm 0.5, \quad 16.1 \pm 0.4, \quad 15.6 \pm 0.4$, and $16.1 \pm 0.6 \mathrm{~mol} \% \mathrm{MgCO}_{3}$ in the $400 T, 400 T+3,700 T$, and $700 T+3$ treatments, respectively. The $\mathrm{Mg}$ content was 
not affected by temperature or $p \mathrm{CO}_{2}$ (Tables $2 \mathrm{~b}, \mathrm{~S} 2$ ). There was minor asymmetry on the higher $\mathrm{mol} \% \mathrm{MgCO}_{3}$ side of magnesium calcite XRD peaks indicating the presence of a higher magnesium calcite phase (Fig. 3). However, this asymmetry did not extend over the dolomite position suggesting the extra phase was a second magnesium calcite. The difference in $\mathrm{mol} \% \mathrm{MgCO}_{3}$ when incorporating the extra asymmetry into the calculations (see Nash et al., 2013b, for full discussion on this method) showed that the asymmetry was also not affected by temperature or $p \mathrm{CO}_{2}$ (Table 3).

\subsection{Dissolution chips}

The mean $( \pm \mathrm{SD}) \mathrm{Mg}$ contents of dissolution chips were $15.4 \pm 0.5, \quad 15.6 \pm 0.5, \quad 15.6 \pm 0.5$, and $15.5 \pm 0.4 \mathrm{~mol} \%$ $\mathrm{MgCO}_{3}$ in the $400 T, 400 T+3,700 T$, and $700 T+3$ treatments, respectively. The $\mathrm{Mg}$ content was not affected by temperature or $p \mathrm{CO}_{2}$ (Tables $2 \mathrm{c}, \mathrm{S} 3$ ). The average $\mathrm{Mg}$ content was significantly lower in the dissolution chips than in main thalli $\left(15.5 \pm 0.4\right.$ vs. $16.0 \pm 0.5 \mathrm{~mol} \% \mathrm{MgCO}_{3}, t$ test, $p<0.001$; Fig. 3a, b). Similarly to the main thalli, there was a minor asymmetry on the higher $\mathrm{mol} \% \mathrm{MgCO}_{3}$ side of the magnesium calcite XRD peak, indicating a second phase of magnesium calcite with higher $\mathrm{Mg}$ content (Fig. 3b). The difference in asymmetry was lower for the dissolution chips than the main thalli ( $t$ test, $p=0.008$; Fig. $3 \mathrm{c}$ ) and was not affected by temperature or $p \mathrm{CO}_{2}$ (Table 3 ).

\section{Discussion}

Results obtained on the new crust demonstrate that the mineralogy of $L$. cabiochae is primarily controlled by temperature and scarcely constrained by $p \mathrm{CO}_{2}$. Similarly, the $\mathrm{Mg}$ content does not respond to $p \mathrm{CO}_{2}$ in dead CCA skeleton but decreases in all dead crusts over the 12-month experiment. Thus our hypothesis that the Mg content would increase with temperature is supported but the hypothesis that $\mathrm{Mg}$ content would decrease with $p \mathrm{CO}_{2}$ is not. Seawater temperature is effectively considered to exert primary control on $\mathrm{Mg}$ content in coralline algae (Halfar et al., 2000; Kamenos et al., 2008). In L. cabiochae, an increase of $3{ }^{\circ} \mathrm{C}$ above ambient temperature led to an increase in $\mathrm{Mg}$ incorporation of $1 \mathrm{~mol} \% \mathrm{MgCO}_{3},\left(0.33 \mathrm{~mol} \% \mathrm{MgCO}_{3} /{ }^{\circ} \mathrm{C}\right)$, which is consistent with the values reported in the literature, both experimentally and in situ, ranging between 0.3 and $2 \mathrm{~mol} \%$ $\mathrm{MgCO}_{3}$ per ${ }^{\circ} \mathrm{C}$ (Chave and Wheeler, 1965; Halfar et al., 2000; Kamenos et al., 2008; Hetzinger et al., 2009; Caragnano et al., 2014; Diaz-Pulido et al., 2014; Williamson et al., 2014). Conversely, $p \mathrm{CO}_{2}$ did not drive significant change in the $\mathrm{Mg}$ content of living L. cabiochae.

The $\mathrm{Mg}$ content of the pink surficial crust was higher in the elevated temperature treatments, and while no statistical analyses could be carried out, these results are consis- tent with the increase in $\mathrm{Mg}$ measured for pink surficial crust as a function of increasing temperature reported in previous work (Diaz-Pulido et al., 2014). The lower Mg content recorded for the pink surficial crust relative to the bulk crust is in agreement with previous studies on CCA Porolithon onkodes (Diaz-Pulido et al., 2014; Nash et al., 2015). Sampling of the surface aims to capture predominantly epithallial carbonate. The epithallial cells of corallines are typically different in shape to the perithallial cells, being shorter and flattened or ovoid shape (e.g. Pueschel and Keats, 1997). It is not presently known why the epithallus has a lower $\mathrm{Mg}$ than the bulk perithallus or whether this offset is common to all species. However, the close agreement of the temperature response for the $P$. onkodes surficial crust of $0.37 \mathrm{~mol} \% \mathrm{MgCO}_{3} /{ }^{\circ} \mathrm{C}$ (Diaz-Pulido et al., 2014) with the $0.33 \mathrm{~mol} \% \mathrm{MgCO}_{3} /{ }^{\circ} \mathrm{C}$ measured for the new crust in this experiment does suggest the controls on $\mathrm{Mg}$ uptake are similar for both the perithallial and epithallial cells.

The consistent shift of $\sim 0.33 \mathrm{~mol} \% \mathrm{MgCO}_{3} /{ }^{\circ} \mathrm{C}$ across both the control and $\mathrm{CO}_{2}$ treatments, considered together with the results for Diaz-Pulido et al. (2014) of $0.37 \mathrm{~mol} \% \mathrm{MgCO}_{3} /{ }^{\circ} \mathrm{C}$ from a $2{ }^{\circ} \mathrm{C}$ increase, suggests the magnesium change is a robust temperature response and this is of interest for CCA palaeotemperature proxies (e.g. Halfar et al., 2000; Kamenos et al., 2008; Hetzinger et al., 2009). This increase in $\mathrm{Mg}$ content is also in agreement with results obtained by XRD of articulate corallines (0.286-0.479 mol \% $\mathrm{MgCO}_{3} /{ }^{\circ} \mathrm{C}$; Williamson et al., 2014) and a variety of species $\left(0.36 \mathrm{~mol} \% \mathrm{MgCO}_{3} /{ }^{\circ} \mathrm{C}\right.$ using only XRD results in Chave, 1954) collected across a geographical temperature range. The reports of ratios of up to $2 \mathrm{~mol} \% \mathrm{MgCO}_{3} /{ }^{\circ} \mathrm{C}$ (Halfar et al., 2000; Kamenos et al., 2008; Hetzinger et al., 2009; Caragnano et al., 2014; Williams et al., 2014) may be due to different analytical methods or species-specific effects. The similarity of the results obtained using XRD for both experimental and in situ corallines supports using a ratio of $\sim 0.3$ to $0.4 \mathrm{~mol} \% \mathrm{MgCO}_{3} /{ }^{\circ} \mathrm{C}$ as a palaeothermometer when the analytical methods return an effective spatial average for magnesium calcite and the absence of other carbonates; aragonite, low-magnesium calcite, dolomite, and magnesite have been confirmed.

The new crusts represent the average $\mathrm{mol} \% \mathrm{MgCO}_{3}$ influenced by the temperature experienced during their growth, which is unlikely to be an even representation of the entire experimental duration. This is for two reasons. First, growth rate varies with temperature, which could result in a bias towards warmer-month Mg content. Secondly, although the progression of the new crust growth was not specifically monitored throughout the experiment, it is likely that a relatively small amount of the final material would have formed during these first few months. For the new growths to form, initially new hypothallial cells would have to bud out and then change to perithallial cells, which form the bulk of CCA crust material. The experiment started and fin- 

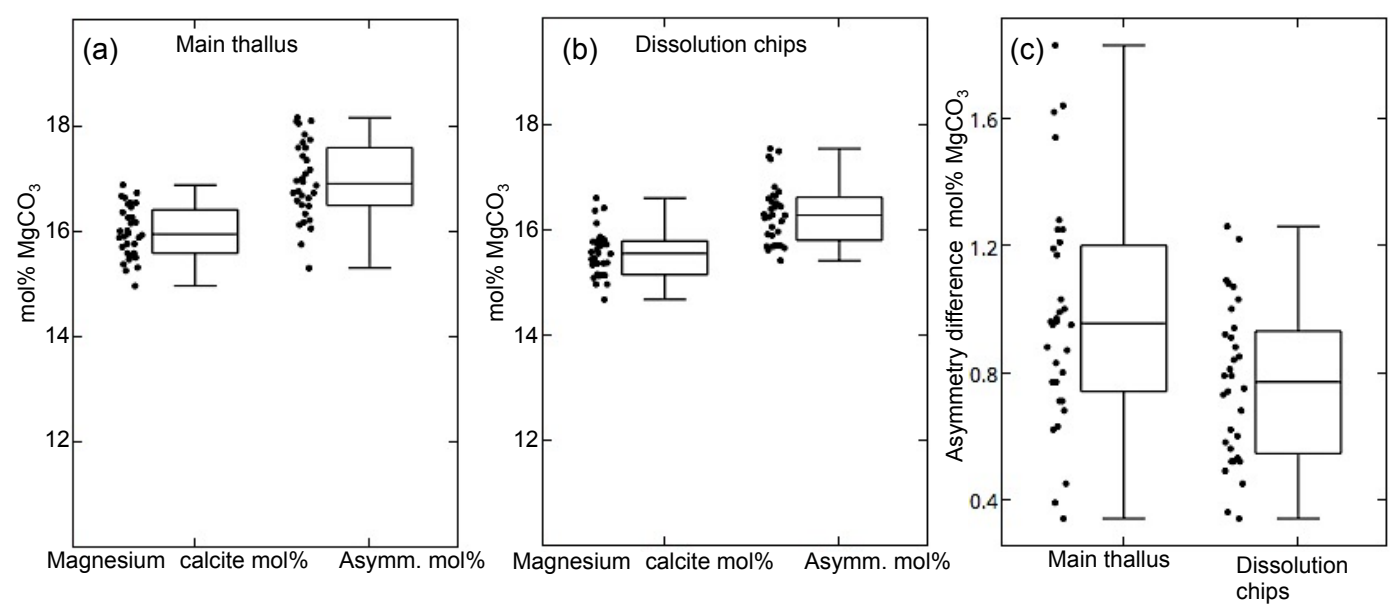

Figure 3. $\mathrm{XRD}$ results for main thalli and dissolution chips. (a)The mol $\% \mathrm{MgCO}_{3}$ and asymmetry mol $\% \mathrm{MgCO}_{3}$ for the main thallus. The (b) $\mathrm{mol} \% \mathrm{MgCO}_{3}$ and asymmetry mol $\% \mathrm{MgCO}_{3}$ for the dissolution chips. (c) Difference in asymmetry mol $\% \mathrm{MgCO}_{3}$ between the main thallus and dissolution chips indicating a reduction in the higher phases of magnesium calcite after dissolution.

ished in summer, July. The warmest months were July, August, and September (Martin et al., 2009). Calcification rates during autumn, winter, and spring ranged from $\sim 0.02$ to $0.15 \mu \mathrm{mol} \mathrm{CaCO}_{3} \mathrm{~cm}^{-2} \mathrm{~h}^{-1}$, in contrast to the substantially higher rates of $0.3-0.52 \mu \mathrm{mol} \mathrm{CaCO}_{3} \mathrm{~cm}^{-2} \mathrm{~h}^{-1}$ during summer months (Martin et al., 2013a). While growth may have commenced during the summer, probably most of the crust formed over the remainder of the experimental period, autumn, winter, and spring. However, that there was no significant difference in mineralogy between the treatments except for the temperature influence suggests that all crusts analysed grew over similar time frames: each crust has similar proportions of growth from the differing temperature and time periods.

Prior to utilizing CCA as a temperature proxy, it is necessary to verify that the $\mathrm{Mg}$ in the magnesium calcite is the primary $\mathrm{Mg}$ incorporated during calcification and not the result of diagenesis. The depletion of $\mathrm{Mg}$ in the dissolution experiment crusts over 8 months indicates this change can be relatively rapid once the organism is no longer protected by living tissue. This is likely to be more of a problem when using fossil branching corallines than thick crusts that retain a living surface layer. Indeed, Kamenos et al. (2008) noted their sub-fossil Lithothamnion glaciale had significantly lower $\mathrm{Mg}$ in the summer season than their living samples. The likelihood of remineralization was considered by Kamenos et al. but rejected, as remineralization was presumed to be to either low magnesium calcite or aragonite. The possibility of remineralization to a lower phase of magnesium calcite, as has occurred in this experiment and noted at the base of CCA Porolithon onkodes (Nash et al., 2013b), had not previously been reported. The present study experimentally confirms that diagenesis does not necessarily mean a change to aragonite or low magnesium calcite, but instead it can be to a lower phase of magnesium calcite, thus making it more dif- ficult to detect post-mortem diagenesis from $\mathrm{Mg}$ measurements or mineralogy alone. High-magnification SEM work would be required to check for remineralization.

Analyses of the preexisting thalli (main thalli) provide a baseline $\mathrm{Mg}$ content for pre-experimental $L$. cabiochae with the assumption that this has not changed during the experiment. The average across treatments was $16.1 \mathrm{~mol} \% \mathrm{MgCO}_{3}$, excluding the $700 T$ treatment. This $\mathrm{Mg}$ content is higher than that of the new crusts grown under ambient temperatures ( $400 T$ and $700 T$ ) and is probably due to a larger amount of pink surficial crust with lower Mg content in the thin new crusts relative to the preexisting thicker thalli. Although the lower average for $700 T$ is not significantly different from the other three treatments, when this lower $\mathrm{Mg}$ content is considered in the context of the results for the dissolution chips the lower measurement takes on greater relevance. Results for the dissolution chips were not significantly different between treatments with a combined average of $15.5 \mathrm{~mol} \% \mathrm{MgCO}_{3}$. This was significantly lower than the preexisting thalli for all treatments except the $700 T$, suggesting the $700 \mathrm{~T}$ main thalli may have undergone alteration similarly to the dissolution chips during the experiment. The values for $700 T$ were compared by $t$ test to the combined dataset for $400 T, 400 T+3$, and $700 T+3$ and were significantly lower than the group, $p=0.0531$.

Ideally when carrying out experiments where it is planned to analyse the crust, for either mineral or structural changes, it is best when a subsample is taken from each piece prior to being placed into the experimental tanks. This way it can be established that post-experiment crust features are truly representative of the environmental sample (e.g. Nash et al., 2013a) and have not been altered by virtue of being placed in tanks for the duration, as is suspected for $700 T$. Problematically some CCAs exhibit changes in growth unrelated to treatment after being placed in tanks (Nash et al., 2015). 
Thus best practice would be to set aside subsamples, particularly where a species has not already been well studied at the cellular scale so that it can be determined whether the control tanks result in growth and mineral composition comparable to in situ growth.

It is interesting to consider why the dissolution chips have lower $\mathrm{Mg}$ content than the main thalli when they were subsamples of the same. Presumably, because the thalli remained covered in living tissue, this has substantially protected the crust from exposure to ambient seawater, whereas the dissolution chips had direct exposure to seawater. Assuming that the dissolution chips initially had the same $\mathrm{Mg}$ content as the main thalli from which they were subsampled, then the lower $\mathrm{Mg}$ content after 8 months of direct exposure to seawater indicates there has been alteration of the crust. All chips lost weight over the 8 months (Martin and Gattuso, 2009) with those in the $700 T$ and $700 T+3$ treatments having the highest dissolution rates. However, the absence of a trend for $\mathrm{Mg}$ content with treatment indicates that dissolution rates do not influence the thermodynamics of the magnesium calcite dissolution process for these CCAs. The strong correlation with $\mathrm{CO}_{2}$ and dissolution rates in the original experiment (Martin et al., 2009) suggests that the seawater $\mathrm{pH}$ is the dominant factor in driving dissolution. Indeed micro-bioerosion can increase in response to that, as shown in Diaz-Pulido et al. (2014), but the mechanism by which they could influence the $\mathrm{Mg}$ content of the magnesium calcite is not yet known. Further work is planned to analyse these dissolution chips by SEM-EDS, which may shed light on the process.

Theory suggests that the higher phases of magnesium calcite will dissolve first (Andersson et al., 2008), but microstructural properties may interfere with a purely thermodynamic response (Morse et al., 2007; Henrich and Wefer, 1986; Walter and Morse, 1985, reviewed in Eyre et al., 2014; Pickett and Andersson, 2015). The lowest phase in the $L$. cabiochae is the pink surficial crusts, but they do not make up a substantial amount of the main thalli bulk sample. The presence of asymmetry indicates an extra phase of magnesium calcite with a higher content of $\mathrm{Mg}$. Previous works on cold water (Adey et al., 2013) and tropical (Nash et al., 2013a) CCAs have shown that the cell wall and inter-filament regions have visually different crystal morphology. It may be that they have different $\mathrm{Mg}$ content although this hypothesis has not been tested yet. Statistical results showed lower asymmetry for the dissolution chips compared to the main thallus. This indicates that the relative proportion of higher-Mg-phase magnesium calcite was less in the dissolution chips suggesting that the higher $\mathrm{Mg}$ phase, while still present, had suffered greater dissolution relative to the lower$\mathrm{Mg}$ phases. Dissolution experiments have demonstrated that the inter-filament magnesium calcite is the first to dissolve in pH 8 (NBS) after $1 \mathrm{~h}$ (Nash et al., 2013), and the cell walls remain intact until exposed to $\mathrm{pH}$ 7.7-7.82 over several hours. The $\mathrm{pH}$ in the present experiment did not drop below $\mathrm{pH}_{\mathrm{T}} 7.8$ in the $700 T$ or $700 T+3$ treatments (Martin and Gattuso,
2009). Considering these previous studies and the data presented here, it seems likely that the cell walls have remained substantially intact, but the inter-filament magnesium calcite has remineralized to a lower phase of magnesium calcite, and there may also be abiotic magnesium calcite infilling cell spaces prior to complete dissolution of the exposed edge. The process of cell infill by magnesium calcite has been observed in the exposed bases of tropical CCA P. onkodes (Nash et al., 2013a) whereby exposed dead cells are in-filled with magnesium calcite. XRD analyses of the exposed base of the tropical CCA measured $14.8 \mathrm{~mol} \% \mathrm{MgCO}_{3}$ compared to the main crust of $16.9 \mathrm{~mol} \% \mathrm{MgCO}_{3}$ (Nash et al., 2013b) indicating that the abiotic magnesium calcite has lower average $\mathrm{Mg}$ content than the original crust.

If the proposal for remineralization of the dissolution chips is correct, then the results for the present study would indicate that there is no trend with $\mathrm{Mg}$ and temperature or $\mathrm{CO}_{2}$ for abiotic mineral formation. This would be in contrast to results for synthetic formation of magnesium calcite (Mucci, 1987) although the trend for synthetic Mg content was substantially less sensitive than uptake for biogenic magnesium calcite, with an increase of only $2 \mathrm{~mol} \% \mathrm{MgCO}_{3}$ from 6 to $8 \mathrm{~mol} \% \mathrm{MgCO}_{3}$ from 5 to $25^{\circ} \mathrm{C}$. Support is provided for the absence of temperature trend by another comparison of the results for the dissolution chips to dead tropical CCAs sampled from a coral reef core from Rodrigues Island, Indian Ocean (Rees et al., 2005), where the Mg content of the dead crusts was 15 to $15.3 \mathrm{~mol} \% \mathrm{MgCO}_{3}$ (Nash et al., 2013b). To thoroughly test the hypothesis for an absence of temperature trend in abiotic magnesium calcite mineralization, a comprehensive survey of dead CCAs from a range of latitudes would be required. However, the clear trend for increase in $\mathrm{Mg}$ uptake by living CCAs as temperature increases, compared to the absence of trend in altered dissolution chips, suggests the $\mathrm{Mg}$ content increase may be primarily driven by a biological response, rather than abiotic thermodynamics alone that the organism is unable to compensate for, as suggested by Diaz-Pulido et al. (2014).

Although earlier studies on $\mathrm{Mg}$ incorporation in the skeleton of coralline algae grown experimentally have found a decline in $\mathrm{Mg}$ content with higher $p \mathrm{CO}_{2}$, likely conferring them a better resistance to dissolution (Agegian, 1985; Ries, 2011; Egilsdottir et al., 2013; Ragazzola et al., 2016), the lack of a $p \mathrm{CO}_{2}$ effect in $L$. cabiochae is consistent with recent findings (Kamenos et al., 2013; Diaz-Pulido et al., 2014; Nash et al., 2015) suggesting that skeletal mineralogy may be under biological control. The organic substrate may provide a template for a baseline magnesium proportion, which then only changes in response to temperature. The ability of coralline algae to control the carbonate chemistry $\left(\mathrm{pH} / p \mathrm{CO}_{2}\right.$ and carbonate saturation state) of the calcifying medium through metabolic activities could enable them to continue to deposit magnesium calcite with a relatively high $\mathrm{mol} \% \mathrm{MgCO}_{3}$ despite changes in the carbonate chemistry driven by ocean acidification (Kamenos et al., 2013, Diaz- 
Pulido et al., 2014) as has been inferred for other magnesium calcite organisms (Ries, 2011). A biological control of mineralization by coralline algae has already been inferred in $L$. cabiochae because its rate of calcification is maintained or even enhanced under elevated $p \mathrm{CO}_{2}$ (Martin et al., 2013a).

It is worth considering whether there is a compensatory mechanism enabling Mg-content maintenance in the elevated $p \mathrm{CO}_{2}$ treatment. This consideration implies that the $\mathrm{Mg}$ content automatically declines with lower $\mathrm{pH}$ (the hypothesis we tested) and the organism must therefore have compensated because the results showed no difference with $p \mathrm{CO}_{2}$. While there have been many studies on $\mathrm{Mg}$ content responses to elevated $p \mathrm{CO}_{2}$ treatments (e.g. Ries, 2011; Egilsdottir et al., 2013; Kamenos et al., 2013; Diaz-Pulido et al., 2014; Nash et al., 2015; Ragazzola et al., 2016) as yet, there has been no study on the internal cellular-scale metabolic controls on $\mathrm{Mg}$ uptake in coralline algae. That is, the controls of Mg uptake are unknown. Is it the internal carbonate chemistry, the type of organic substrate, or a combination of both? Without an understanding of the physiological mechanisms that control Mg uptake, it is impossible to do more than speculate about potential compensatory metabolic processes. This inhibition to carrying out an informed analysis of potential metabolic controls on $\mathrm{Mg}$ uptake highlights the need for basic scientific investigation into how coralline algae calcify and what roles the anatomy and organic substrates play in calcification and $\mathrm{Mg}$ uptake. Then, we could start to understand how these processes react to external environmental changes. Ragazzola et al. $(2013,2016)$ and Hofmann et al. (2012) have shown anatomical changes in response to $p \mathrm{CO}_{2}$ that may be ameliorated over longer time periods, but the exact controls on those changes are not known. Recent work has demonstrated the capacity of CCA to maintain elevated $\mathrm{pH}$ in the boundary layer $(\sim 100 \mu \mathrm{m}$ thick, dependent on water motion) when ambient seawater $\mathrm{pH}$ is reduced (Hofmann et al., 2016). The maintenance of the $\mathrm{Mg}$ content, if it is related to $\mathrm{pH}$ or saturation state, may be enabled by the organism's capacity to control boundary layer $\mathrm{pH}$ and thus effectively inhibit the treatment $\mathrm{pH}$ from reaching the living surface.

It remains unclear to what extent the algal metabolism exerts a control on magnesium carbonate chemistry as different effects of $p \mathrm{CO}_{2}$ on the $\mathrm{Mg}$ content and calcification rates have been found in other species of coralline algae (Ries, 2011; Ragazzola et al., 2013, 2016). The increase in $\mathrm{Mg}$ content at elevated temperature may lead to increased thalli dissolution, but this could be offset by increased calcification (Martin et al., 2013a). However, the enhanced mortality under the combination of projected ocean warming and acidification (Martin and Gattuso, 2009) could have major consequences for the physical stability and maintenance of coralligenous habitats that outweigh any adaptive mineral response. Further work to understand the process that leads to lower Mg content in the dead algal chips post-mortem would shed light on remineralization of CCA post-mortem.

\section{Data availability}

All raw data used for statistical analyses are included in the Supplement.

\section{The Supplement related to this article is available online at doi:10.5194/bg-13-5937-2016-supplement.}

Author contributions. Sophie Martin and Jean-Pierre Gattuso conceived and carried out the experimental work. Merinda C. Nash carried out the mineral analyses. All authors contributed to writing the manuscript.

Competing interests. Authors declare no existing competing financial interests in this work.

Acknowledgements. This work was supported by the CarboOcean IP of the European Commission (grant 511176-2) and is a contribution to the European Project on Ocean Acidification (EPOCA), which received funding from the European Community (grant agreement 211384).

Edited by: L. de Nooijer

Reviewed by: B. Steneck and two anonymous referees

\section{References}

Adey, W. H., Halfar, J., and Williams, B.: The coralline genus Clathromorphum Foslie emend, Adey: Biological, physiological, and ecological factors controlling carbonate production in an Arctic-Subarctic climate archive, Smithsonian contributions to the marine sciences, 40, 1-41, 2013.

Agegian, C. R.: The biogeochemical ecology of Porolithon gardineri (Foslie), PhD dissertation, University of Hawaii, 1985.

Andersson, A. J., Mackenzie, F. T., and Bates, N. R.: Life on the margin: implications of ocean acidification on $\mathrm{Mg}$-calcite, high latitude and cold-water marine calcifiers, Mar. Ecol.-Prog. Ser., 373, 265-273, 2008.

Caragnano, A., Basso, D., Jacob, D.E., Storz, D., Rodondi, G., Benzoni, F., and Dutrieux, E.: The coralline red alga Lithophyllum kotschyanum $\mathrm{f}$. affine as proxy of climate variability in the Yemen coast, Gulf of Aden (NW Indian Ocean), Geochim. Cosmochim. Ac., 124, 1-17, 2014.

Chave, K. E. and Wheeler, B. D.: Mineralogic changes during growth in the red alga, Clathromorphum compactum, Science, 147, 621-621, 1965.

Diaz-Pulido, G., Nash, M. C., Anthony, K. R. N., Bender, D., Opdyke, B. N., Reyes-Nivia, C., and Troitzsch, U.: Greenhouse conditions induce mineralogical changes and dolomite accumulation in coralline algae on tropical reefs, Nat. Commun., 5, 3310, doi:10.1038/ncomms4310, 2014. 
Egilsdottir, H., Noisette, F., Laure, M. L. N., Olafsson, J., and Martin, S.: Effects of $p \mathrm{CO}_{2}$ on physiology and skeletal mineralogy in a tidal pool coralline alga Corallina elongate, Mar. Biol., 160, 2103-2112, 2013.

Eyre, B. D., Andersson, A. J., and Cyronak ,T.: Benthic coral reef calcium carbonate dissolution in an acidifying ocean, Nature Climate Change, 4, 969-976, 2014.

Halfar, J., Zack, T., Kronz, A., and Zachos, J. C.: Growth and high resolution palaeoenvironmental signals of rhodoliths coralline red algae: a new biogenic archive, J. Geophys. Res.-Oceans, 105, 22107-22116, 2000.

Henrich, R. and Wefer, G.: Dissolution of biogenic carbonates: Effects of skeletal structure, Mar. Geol., 71, 341-362, 1986.

Hetzinger, S., Halfar, J., Kronz, A., Steneck, R. S., Adey, W., Lebednik, P. A., and Schöne, B. R.: High-resolution $\mathrm{Mg} / \mathrm{Ca}$ rations in coralline red alga as a proxy for Bering Sea temperature variations from 1902 to 1967, Palaios, 24, 406-412, 2009.

Hofmann, L. C., Yildiz, G., Hanelt, D., and Bischof, K: Physiological responses of the calcifying rhodophyte, Corallina officinalis (L.), to future $\mathrm{CO}_{2}$ levels, Mar. Biol., 159, 783-792, 2012.

Hofmann, L. C., Koch, M., and de Beer, D., Biotic Control of Surface $\mathrm{pH}$ and Evidence of Light-Induced $\mathrm{H}+$ Pumping and $\mathrm{Ca}$ 2+-H+ Exchange in a Tropical Crustose Coralline Alga, PloS one, 11, e0159057, doi:10.1371/journal.pone.0159057, 2016.

Kamenos, N. A., Cusack, M., and Moore, P. G.: Coralline algae are global palaeothermometers with bi-weekly resolution, Geochim. Cosmochim. Ac., 72, 771-779, 2008.

Kamenos, N. A., Burdett, H. L., Aloisio, E., Findlay, H. S., Martin, S., Longbone, C., Dunn, J., Widdicombe, S., and Calosi, P.: Coralline algal structure is more sensitive to rate, rather than the magnitude, of ocean acidification, Glob. Change Biol., 19, 3621$3628,2013$.

Kline, D. I., Teneva, L., Schneider, K., Miard, T., Chai, A., Marker, M., Headley, K., Opdyke, B., Nash, M., Valetich, M., Caves, J. K., Russell, B. D., Connell, S. D., Kirkwood, B. J., Brewer, P., Peltzer, E., Silverman, J.,, Caldeira, Dunbar, R. B., Koseff, J. R., Monismith, S. G., Mitchell, B. G., Dove, S., and Hoegh-Guldberg, O.: A short-term in situ $\mathrm{CO}_{2}$ enrichment experiment on Heron Island (GBR), Sci. Rep., 2, 413, doi:10.1038/srep00413, 2012.

Martin, S. and Gattuso, J.-P.: Response of Mediterranean coralline algae to ocean acidification and elevated temperature, Glob. Change Biol. 15, 2089-2100, 2009.

Martin, S., Cohu S., Vignot, C., Zimmerman, G., and Gattuso, J.P.: One-year experiment on the physiological response of the Mediterranean crustose coralline alga, Lithophyllum cabiochae, to elevated $p \mathrm{CO}_{2}$ and temperature, Ecol. Evol., 3, 676-693, 2013a.

Martin, S., Charnoz A., and Gattuso, J.-P.: Photosynthesis, respiration and calcification in the Mediterranean crustose coralline alga Lithophyllum cabiochae (Corallinales, Rhodophyta), Eur. J. Phycol., 48, 163-172, 2013b.

Morse, J. W., Arvidson, R. S., and Lüttge, A.: Calcium carbonate formation and dissolution, Chem. Rev., 107, 342-381, 2007.
Mucci, A.: Influence of temperature on the composition of magnesian calcite overgrowths precipitated from seawater, Geochim. Cosmochim. Ac., 51, 1977-1984, 1987.

Nash, M. C., Troitzsch, U., Opdyke, B. N., Trafford, J. M., Russell, B. D., and Kline, D. I.: First discovery of dolomite and magnesite in living coralline algae and its geobiological implications, Biogeosciences, 8, 3331-3340, doi:10.5194/bg-8-3331-2011, 2011.

Nash, M. C., Opdyke, B. N., Troitzsch, U., Russell, B. D., Adey, W. H., Kato, A., Diaz-Pulido, G., Brent, C., Gardner, M., Prichard, J., and Kline, D. I.: Dolomite-rich coralline algae in reefs resist dissolution in acidified conditions, Nature Climate Change 3, 268-272, 2013a.

Nash, M. C., Opdyke, B. N., Wu, Z., Xu, H., and Trafford, J. M.: Simple X-Ray Diffraction Techniques To Identify MG Calcite, Dolomite, and Magnesite In Tropical Coralline Algae and Assess Peak Asymmetry, J. Sed. Res., 83, 1084-1098, 2013b.

Nash, M. C., Uthicke, S., Negri, A. P., and Cantin, N. E.: Ocean acidification does not affect magnesium composition or dolomite formation in living crustose coralline algae, Porolithon onkodes in an experimental system, Biogeosciences, 12, 5247-5260, doi:10.5194/bg-12-5247-2015, 2015.

Pickett, M. and Andersson, A. J.: Dissolution rates of Biogenic Carbonates in Natural Seawater at Different $p \mathrm{CO}_{2}$ Conditions: A Laboratory Study, Aquat. Geochem., 21, 459-485, 2015.

Pueschel, C. M. and Keats, D. W.: Fine structure of deep-layer sloughing and epithallial regeneration in Lithophyllum neoatalayense (Corallinales, Rhodophyta), Phycol. Res., 45, 1-8, 1997.

Ragazzola, F., Foster, L. C., Form, A. U., Büscher, J., Hansteen, T. H., and Fietzke, J.: Phenotypic plasticity of coralline algae in a High $\mathrm{CO}_{2}$ world, Ecol. Evol., 3, 3436-3446, 2013.

Ragazzola, F., Foster, L. C., Jones, C. J., Scott, T. B., Fietzke, J., Kilburn, M. R., and Schmidt, D. N.: Impact of high $\mathrm{CO}_{2}$ on the geochemistry of the coralline algae Lithothamnion glaciale, Sci. Rep., 6, 1-9, 2016.

Rees, S. A., Opdyke, B. N. O., Wilson, P. A., and Fifield, L. K.: Coral reef sedimentation on Rodrigues and the Western Indian Ocean and its impact on the carbon cycle, Philos. T. R. Soc. Lond., 363, 101-120, 2005.

Ries, J. B.: Skeletal mineralogy in a high- $\mathrm{CO}_{2}$ world, J. Exp. Mar. Biol. Ecol., 403, 54-64, 2011.

Stanley, S. M., Ries, J. B., and Hardie, L. A.: Low-magnesium calcite produced by coralline algae in seawater of Late Cretaceous composition, P. Natl. Acad. Sci. USA, 99, 15323-15326, 2002.

Walter, L. M. and Morse, J. W.: The dissolution kinetics of shallow marine carbonates in seawater: A laboratory study, Geochim. Cosmochim. Ac., 49, 1503-1513, 1985.

Williams, B., Halfar, J., DeLong, K. L., Hetzinger, S., Steneck, R. S., and Jacob, D. E.: Multi-specimen and multi-site calibration of Aleutian coralline algal $\mathrm{Mg} / \mathrm{Ca}$ to sea surface temperature, Geochim. Cosmochim. Ac., 139, 190-204. 2014

Williamson, C. J., Najorka, J., Perkins, R., Yallop, M. L., and Brodie, J.: Skeletal mineralogy of geniculate corallines: providing context for climate change and ocean acidification research, Mar. Ecol.-Prog. Ser., 513, 71-78, 2014. 